\title{
Magmatic constraints on localization of natural stone deposits in the Vehmaa rapakivi granite batholith, southwestern Finland
}

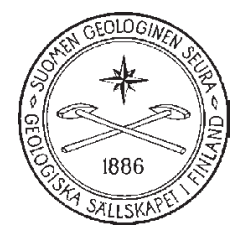

\author{
Olavi Selonen ${ }^{1)^{*}}$, Carl Ehlers ${ }^{1)}$, Hannu Luodes ${ }^{2)}$ \\ AND FREDRIK KARELL ${ }^{1,3)}$ \\ 1) Abo Akademi University, Department of geology and mineralogy, \\ FI-20500 Turku, Finland. \\ 2) Geological Survey of Finland, FI-70211 Kuopio, Finland. \\ 3) Geological Survey of Finland, FI-02151 Espoo, Finland.
}

\begin{abstract}
The 1580-1570 Ma old Vehmaa rapakivi granite batholith was studied with the aim to define the geological constraints for localization of natural stone deposits in the batholith. The batholith comprises four roughly concentric granite intrusions from the margin inwards: pyterlite, coarse-grained porphyritic rapakivi granite and two types of mediumgrained porphyritic rapakivi granite. Also porphyry aplite and even-grained rapakivi granite occur. The batholith has intruded as a succession of pulses of subhorizontal sheet-like intrusions conceivably through repeated cauldron subsidence. Natural stone quarries are confined only to certain intrusions within the batholith. We show that the mediumgrained porphyritc granite body in the centre of the batholith comprises two almost identical but different intrusions, with only slightly different appearances: the inner (IG) and the outer (OG) granite. The quarries are confined to the outer intrusion which has an appearance more attractive to the market than that of the inner intrusion. The localization of the natural stone deposits in the Vehmaa batholith is a result of the magmatic history of the batholith, producing intrusions of different appearances with different commercial potential.
\end{abstract}

Key words: natural stone, building stone, granite deposits, rapakivi, batholiths, magmatism, fractures, mineral exploration, potential deposits, Vehmaa, Finland.

* Corresponding author email: olavi.selonen@abo.fi

Editorial handling: Joonas Virtasalo

\section{Introduction}

The 1580-1570 Ma old Vehmaa rapakivi granite batholith is one of four major rapakivi granite batholiths in Finland (Rämö \& Haapala, 2005). It is located in southwestern Finland and covers an area of $700 \mathrm{~km}^{2}$ (Fig. 1). The Vehmaa batholith is composed of four roughly concentrically arranged 


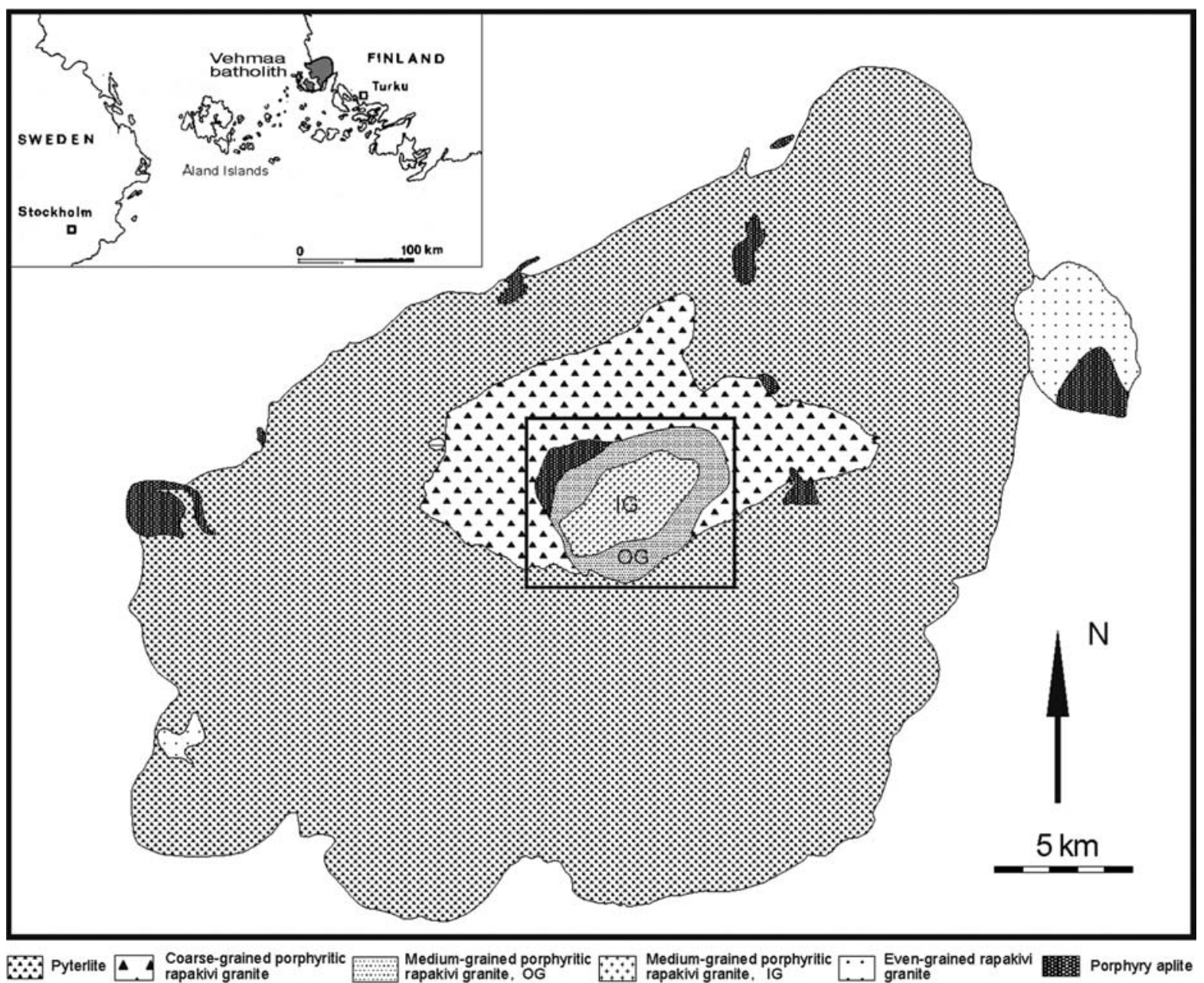

Fig. 1. Geological map of the Vehmaa rapakivi granite batholith. Modified from Lindberg \& Bergman (1993) and Selonen et al. (2005). IG = inner intrusion of the medium-grained porphyritic granite, OG = outer intrusion of the medium-grained porphyritic granite. Location of the Figs. 3, 4, and 7 is indicated with a rectangle.

granite intrusions (from the margins to the centre): pyterlite, coarse-grained porphyritic rapakivi granite, and two types of medium-grained porphyritic rapakivi granite (Fig. 1). Smaller patches of porphyry aplite intrude the main batholith, and a satellite intrusion, consisting of even-grained rapakivi granite occurs as a separate body (Fig. 1). The anorogenic Vehmaa rapakivi granite batholith cuts sharply the older Svecofennian bedrock, post-dating the Svecofennian orogenic ductile deformation.

The Vehmaa batholith represents a classic Finnish stone production area, where the extraction of stone started already in 1901 in the even-grained granite under the commercial name of Balmoral Red
(Selonen \& Härmä, 2003). A couple of years later the production commenced in the outer one of the two concentric medium-grained porphyritic granites in the centre of the Vehmaa batholith (originally close to the shore line due to easier transport of the quarried rock). Today, the granites are commercially known as Balmoral Red coarse-grained (the medium-grained porphyritic granite) and Balmoral Red fine-grained (the even-grained granite). They are well-known Finnish natural stone varieties of global recognition, used in many buildings as facing stone. Other stone qualities produced include the pyterlitic Esko Brown and Antique Brown, but they are quarried in much lesser quantities than the Balmoral 
types (Selonen \& Härmä, 2003).

We have been working in the Vehmaa area on and off for about ten years, starting with evaluation of the natural stone potential, followed by lithological mapping of granite types. According to previous geological maps the batholith was composed of three concentric granite intrusions of pyterlite, coarse-grained porphyritic rapakivi granite, and, in the centre, medium-grained porphyritic rapakivi granite (Kanerva, 1928; Lindberg \& Bergman, 1993). Later we found out that the (economically most productive) medium-grained porphyritic granite body in the middle of the batholith is composed of two separate intrusions (see below and Selonen et al., 2005) (Fig. 1). Our first results were published by Selonen (1998) and Selonen et al. (2000). At that time we had few geophysical data available. Additional geological and geophysical data were reported by Selonen et al. (2005) and Karell et al. (2009). This recent material combined with a revision of the old material enables us now to give a more complete picture of the geological history of the different intrusion phases and their impact on the localization of natural stone quarries in the area. Also, previously unpublished data is included in this article.

The locations of all natural stone (EN 12670, 2001) deposits are constrained by local and regional geological factors. These factors include major fractures, history of intrusion, different intrusion phases, metamorphic grade, and type and direction of deformational structures (Selonen, 1998; Selonen et al., 2000; Lombardero \& García-Guinea, 2001; Carvalho et al., 2008; Heldal et al., 2008; Meriluoto, 2008; Selonen, 2008; Arponen et al., 2009). A combination of factors is often needed in order to produce a rock of desired quality. By studying the local and regional geology in detail, the formation of potential areas and deposits for natural stone can be better understood. Besides explaining the geological conditions required for forming the deposits, the knowledge can ultimately be used in exploration by creating systematic geological prospecting methods and models for natural stone formation.

In this paper we present a specific case of the geological control with the study of the Vehmaa batholith, where natural stone quarries are located only within certain intrusion phases of the batholith. We focused our investigation on the mediumgrained porphyritic granite body, where almost all past and present quarries are concentrated along the marginal parts of the body. What underlying geological factors could have guided experienced quarrymen (without formal geological education) through more than hundred years to areas with stone qualities that were particularly suitable for production? Could we relate these factors to the intrusion history of the batholith?

\section{Quality criteria for natural stone}

As natural stone is almost exclusively selected by architects and used for decorative and ornamental purposes, the appearance is the most important single aspect while choosing a stone for its final application. In assessment of prospects, variations in appearance ("flaws") are considered according to certain criteria (e.g. Heldal \& Arvanitides, 2003). A stone can be evaluated to be homogeneous and suitable for extraction and fulfilling other proven criteria, and yet it will not be quarried, because the appearance is not attractive to the present market. We identify the appearance of a stone as a sum effect of aesthetical components and regard it as a purely commercial concept subject to the shifting tastes of the present markets (cf. Bradley et al., 2004).

Natural stone, e.g. the Balmoral granites, is often quarried for the export market, requiring production of rectangular blocks of large size $\left(2-5 \mathrm{~m}^{3}\right)$. The bedrock must have a suitable pattern and spacing of fractures to allow for the required block size which is constrained by the intended use of the stone and the processing machinery. The macroscopic fracturing must be sparse enough for extraction and the stone material itself must be free from cracks and microfractures.

For other criteria concerning natural stone, including, e.g. location of the deposits and environmental issues, see Shadmon (1996), Primavori (1999), Selonen et al. (2000), Heldal \& Arvaniti- 
des (2003), Lorenz \& Gwosdz (2003), and Bradley et al. (2004).

\section{Research methods}

Our lithological mapping in the batholith was based on the published geological bedrock map of the area by Lindberg \& Bergman (1993). Our main mapping target was the medium-grained porphyritic granite body in the central part of the batholith which was studied in detail. We also revisited some of the contact outcrops between the different intrusions of the batholith for structural observations.

Our general evaluation of the natural stone resources in the Vehmaa batholith included investigation of abandoned and operative quarries as well as assessment of the natural stone potential of the rock types. The main criteria in the evaluations were: visual appearance of the rock, spacing of fractures, size of the deposit, and infrastructural aspects (houses, roads, environment etc.). In our specific evaluation of the medium-grained porphyritic granite body for this paper, the infrastructural aspects were not considered because we wanted to specifically concentrate on the geological aspects of the quality of the granite. The variations in rock appearance were evaluated by eye on outcrops or from polished specimens. The spacing of fractures was evaluated on outcrop by eye or measured by tape along cleaned traverses. Subsurface fracturing was studied with ground penetrating radar (GPR) and core drilling in selected locations.

In order to get a better picture of the intrusion relations an AMS (Anisotropy of Magnetic Susceptibility) study was initiated, focusing on the medium-grained porphyritic granites. Oriented drill core samples were collected for AMS analysis and a few samples for geochemical analysis were taken in the same area (see details in Karell et al. 2009).

During the work we also paid attention to the local (small scale) topography for assessing the relationship between topography, fracture zones and general soundness of the rock. The general elevation in the study area is max. $200 \mathrm{~m}$ and the relative differences in elevation are less than $50 \mathrm{~m}$.

\section{Geological characteristics of the Vehmaa batholith}

\section{1 Rock types}

Pyterlite is the main granite variety in the Vehmaa batholith and surrounds the porphyritic granite types in the central part of the batholith (Fig. 1). It has a typical rapakivi texture with K-feldspar ovoids, occasionally rimmed with plagioclase. The pyterlite is composed of K-feldspar, quartz, plagioclase, biotite, and hornblende. The coarse-grained porphyritic granite is characterized by large, often euhedral, K-feldspar phenocrysts. K-feldspar, quartz, plagioclase, and biotite are the main minerals. The even-grained granite is a satellitic intrusion located at the eastern part of the Vehmaa batholith (Fig. 1), consisting of K-feldspar, quartz, plagioclase, and biotite. The porphyry aplite is a fine to medium-grained rock with scarce unmantled ovoids and feldspar phenocrysts. It occurs as small intrusions at the margins of the different rapakivi types or at the outer margins of the batholith (Fig. 1). For more details on these rock types, see Lindberg \& Bergman (1993) and Selonen et al. (2005).

\subsubsection{Medium-grained porphyritic granites}

The body of medium-grained porphyritic granite occurs in the central parts of the Vehmaa batholith (Fig. 1). Our lithological mapping revealed that the granite is in fact composed of two distinct but very similar types of granite with a gently dipping and hardly observable but mappable contact (Fig. 1). The two granites are easily distinguished in the aeromagnetic map (see chapter 4.2 below). We have called them the inner granite (IG) (forming a rounded centre) and the outer granite (OG), surrounding the centre (Selonen et al., 2005). The porhyritic texture of both granites is defined by $\mathrm{K}$ feldspar phenocrysts (Fig. 2). Both granites consist 

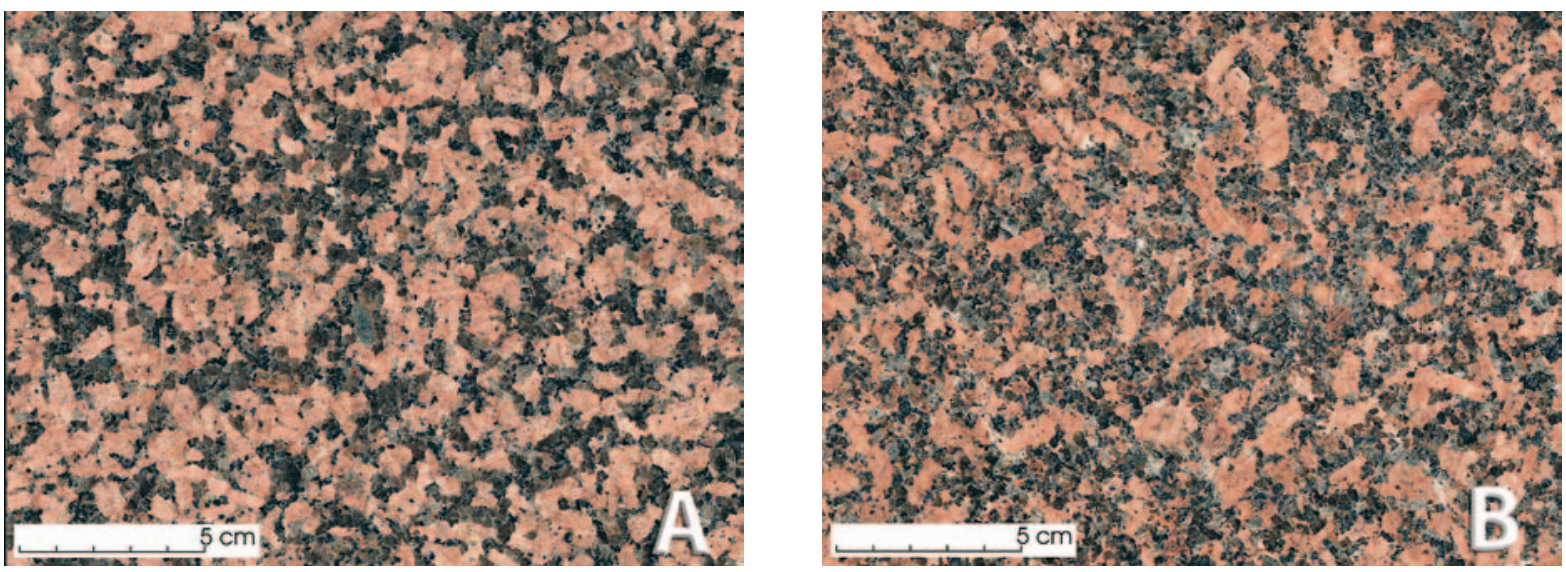

Fig. 2. Two types of medium-grained porphyritic granite. A. outer medium-grained porphyritic granite (OG), B. inner medium-grained porphyritic granite (IG).

of K-feldspar, quartz, plagioclase, and biotite (Lindberg \& Bergman, 1993; Selonen et al., 2005). The two granites differ in mineralogical arrangement. In the outer granite (OG) the K-feldspar phenocrysts are found in clusters in a net-like texture (Fig. 2A). Only few separate euhedral crystals occur in the matrix, single K-feldspar phenocrysts are rarely observed. In the inner granite (IG) the K-feldspars occur as dispersed euhedral crystals, also found separately throughout the matrix (Fig. 2B).

\subsection{Geophysical and geochemical features within the medium- grained porphyritic granites}

The two varieties of the mediumgrained porphyritic granite are distinct in the aeromagnetic map (Selonen et al., 2005; Karell et al., 2009; Fig. 3). The difference shown by a low magnetic susceptibility in the outer granite (OG) and a high magnetic susceptibility in the inner granite (IG) is caused by varying magnetite content in the two grani- tes. Thermomagnetic measurements reveal that the main magnetic mineral responsible for the high magnetic susceptibility in the inner granite (IG) is magnetite while the magnetic susceptibility in the outer granite $(\mathrm{OG})$ is derived from paramagnetic minerals (Karell et al., 2009).

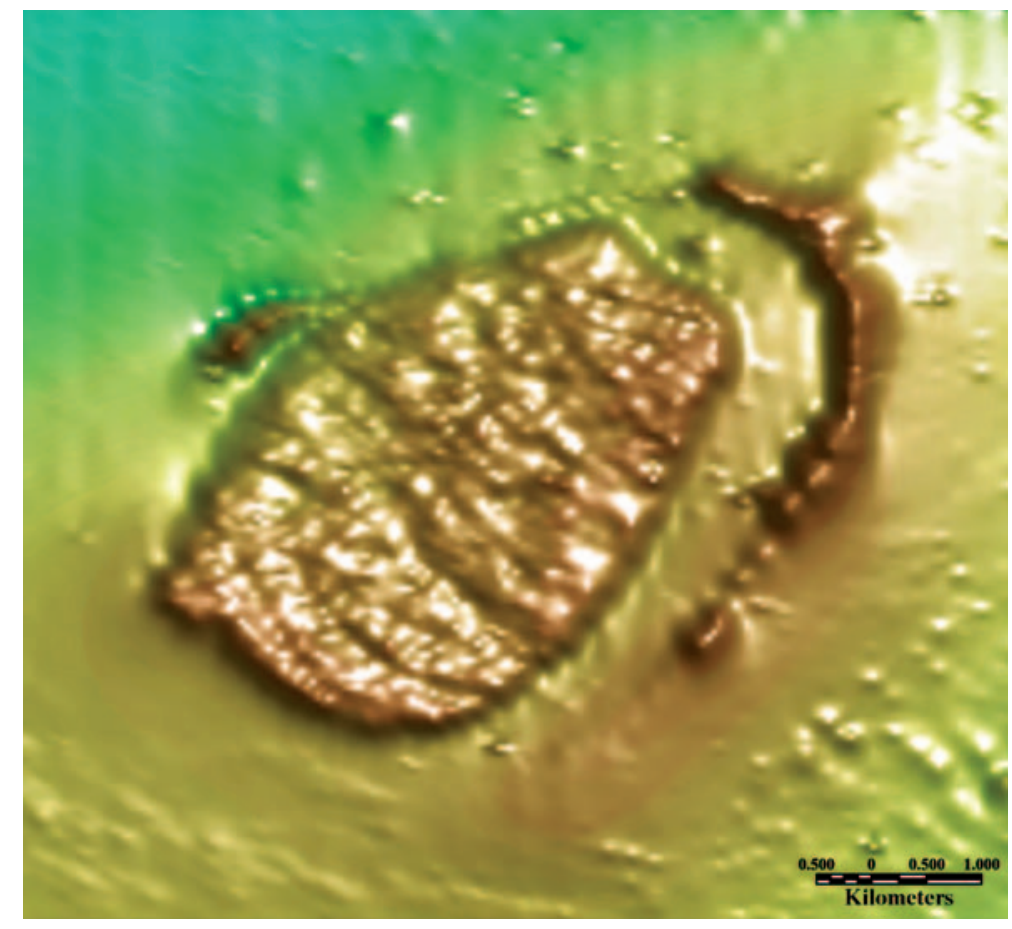

Fig. 3. Aeromagnetic map on the medium-grained porphyritic granite body. Magnetic total component: -180 - 1200 nT (IGRF-65). Composed and modified from Selonen et al. (2005) by J. Lerssi, Geological Survey of Finland. For location, see Fig. 1. 
An AMS (Anisotropy of Magnetic Susceptibility) study indicates that the magnetic fabric is welldeveloped in the inner granite (IG) (Karell et al., 2009), and the strike of the magnetic foliation follows the concentric structure of the intrusive contacts dipping gently outwards, away from the centre (Fig. 4A). The magnetic lineations lie gently, almost horizontally in the middle of the inner granite and strike along the slightly elongated granite body (Fig. 4B). The outer granite (OG) is defined by poorly developed magnetic lineations, while the magnetic foliations are better developed (Karell et al., 2009). The average foliation follows the outer contact of the medium-grained porphyritic granite body against the coarse-grained porphyritic granite. The magnetic susceptibility measurements confirm the results of our initial lithological mapping separating the two granites (IG and OG) as individual intrusions (Selonen et al., 2005; Karell et al., 2009).

The inner and outer granites differ in their geochemical character, implying that the granites represent two differently fractionated pulses of magma (Karell et al., 2009). In the Rb-Ba-Sr diagram (Fig. 4 in Karell et al. 2009) the samples from the inner granite (IG) plot near the Ba corner while the outer granite (OG) is more fractionated and plot towards the $\mathrm{Rb}$ corner. Compared to the outer granite, the inner type is enriched in $\mathrm{MgO}$, $\mathrm{P}_{2} \mathrm{O}_{5}, \mathrm{Al}_{2} \mathrm{O}_{3}$ and $\mathrm{TiO}_{2}$.

\subsection{Contact features and intrusion mechanism}

A striking feature of the contacts of the Vehmaa batholith (and most other rapakivi granite batholiths in southern Finland) is the almost total absence of a violent brecciation of the surrounding host rocks (Lindberg \& Bergman, 1993; Selonen et al., 2005; Karell et al., 2009). The same can be said of the internal contacts between different granite varieties inside the batholith with an exception for sparse single blocks apparently dropping into the intruding granite at the contact (Fig. 5). Most of the external and internal contacts identified, and the structural characteristics of the batholith indicate that the contacts dip gently to moderately away from the batholith (Lindberg \& Bergman, 1993; Selonen et al., 2005; Karell et al., 2009). A good example is the very gently outward dipping sinuous contact between the inner (IG) and the outer (OG) intrusion of the medium-grained porphyritic granite (Selonen et al., 2005). Recently, we found parts of an "umbrella" pattern of gently dipping grey porphyritic aplite dykes around the outer margins of the Vehmaa batholith, dipping away from the batholith and apparently thinning and tapering out a few hundred metres outside the contact (Karell et al., 2009).

The field observations, AMS data, petrology and geochemistry all show that the medium-grained

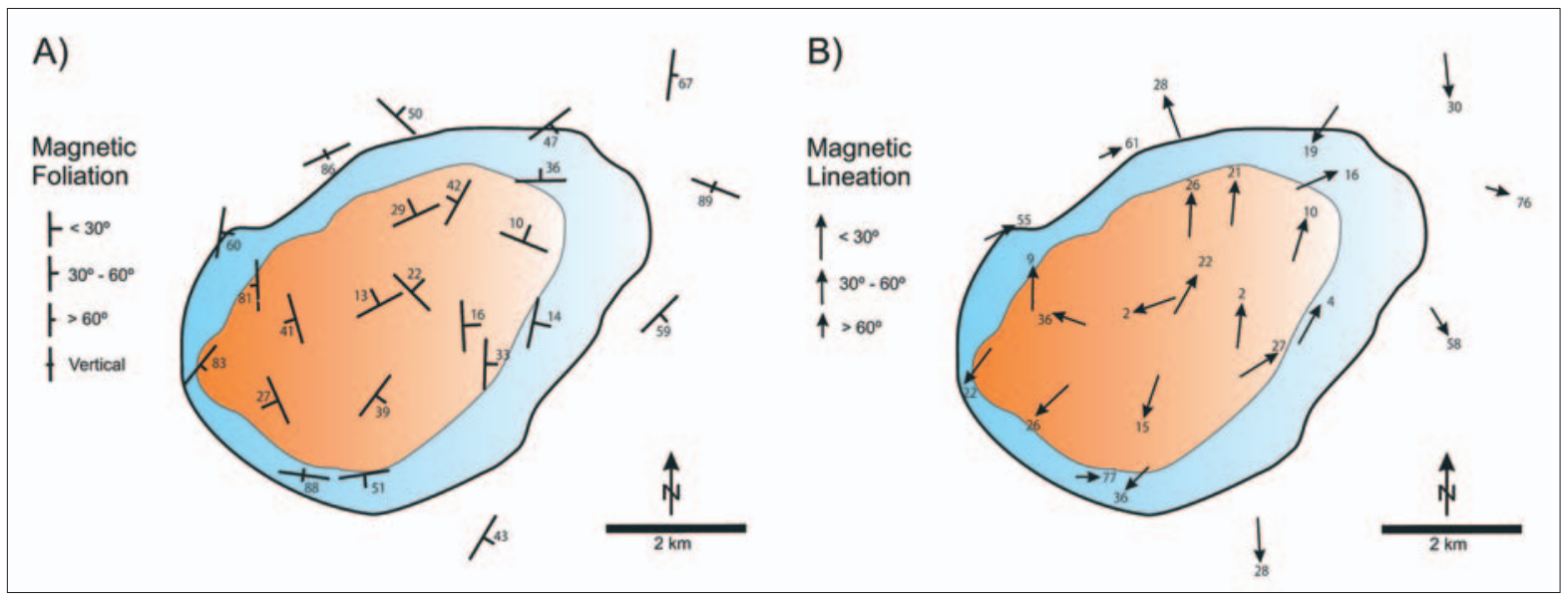

Fig. 4. Magnetic foliation (A) and magnetic lineation (B) in the medium-grained porphyritic granite body. Modified from Karell et al. (2009). For location, see Fig. 1. 


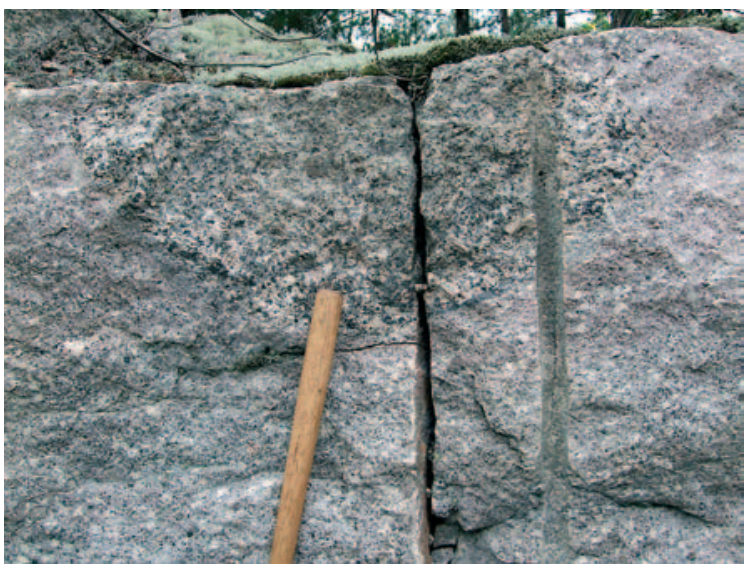

Fig. 5. Inclusion of pyterlitic rapakivi in porphyry aplite at the intrusive contact between the two phases of rapakivi. The exposed part of the hammer handle is $40 \mathrm{~cm}$ in length.

granite body in the centre of the batholith is composed of two separate sheet intrusions of granite (IG and OG) which are by texture almost identical. These facts combined with the contact features of the whole batholith and the concentric structure of the batholith with the relatively oldest granite varieties at the margins of the batholith (Selonen et al., 2005) indicate a collapse-type of intrusion forming a sheet-like structure with a build-up of the batholith by a succession of relative small pulses of magma (Selonen et al., 2005; Karell et al., 2009; Fig. 6). This mechanism involves progressive subsidence of blocks of older gneisses and earlier phases of intrusion, followed by repeated pulses of granite intrusion, i.e. emplacement via repeated cauldron subsidence. Successive, fractioned magma pulses intrude during development of a collapse

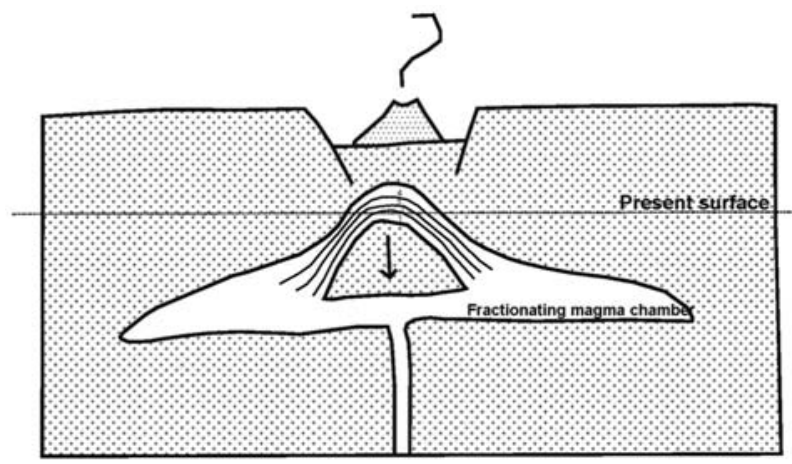

Fig. 6. Intrusion mechanism for the Vehmaa rapakivi granite batholith. See text for explanation. Modified from Selonen et al. (2005). caldera, forming subhorizontal sheets of subvolcanic magma (Fig. 6).

\section{Fractures and topography}

The main vertical fracture zones in the Vehmaa batholith trend in NW-SE and SW-NE directions, transecting all the intrusive phases of the batholith (see also Lindberg \& Bergman, 1993). In the medium-grained porphyritic granite body the main vertical fracture zones are trending in NW-SE direction, forming a pattern of topographical lows including arable lands (Fig. 7). A second set of fracture zones in a direction close to E-W is also seen as distinct topographical lows. A third set of fracture zones trends in a SW-NE direction. Fracture zones of all the directions mentioned above cut both types (IG and OG) of the granite. On outcrops, the NW-SE trending direction is more pronounced in the southwestern and southern parts of the granite body while in the northern and northeastern parts the SW-NE trend dominates.

Massive granite with widely spaced fracturing and with regular fracture pattern is associated with local topographical plateaus with elevations of 25$30 \mathrm{~m}$ over the surrounding terrain. The plateaus are terraced due to regular sheeting (Fig. 8) and form distinct highs in the landscape. The plateaus are often bordered with fracture zones forming topographical lows, as seen in the SW part of the medium-grained porphyritic granite body. The erosional force of the ice (glacial quarrying, e.g. Dühnforth et al., 2010) during the last ice age concentrated especially on those pre-existing fracture zones in the same direction as the movement of the ice, i.e. the NW-SE direction, and sound granite with sparse and regular fracturing, suitable for extraction, is found between the zones. The less fractured parts of the granite between the steep fracture zones have remained as higher local terraced plateaus, implying areas of typical orthogonal fracturing style of rapakivi granite with welldeveloped and wider spaced vertical fracturing and horizontal sheeting. These areas indicate a high potential for natural stone, involving a large volume 


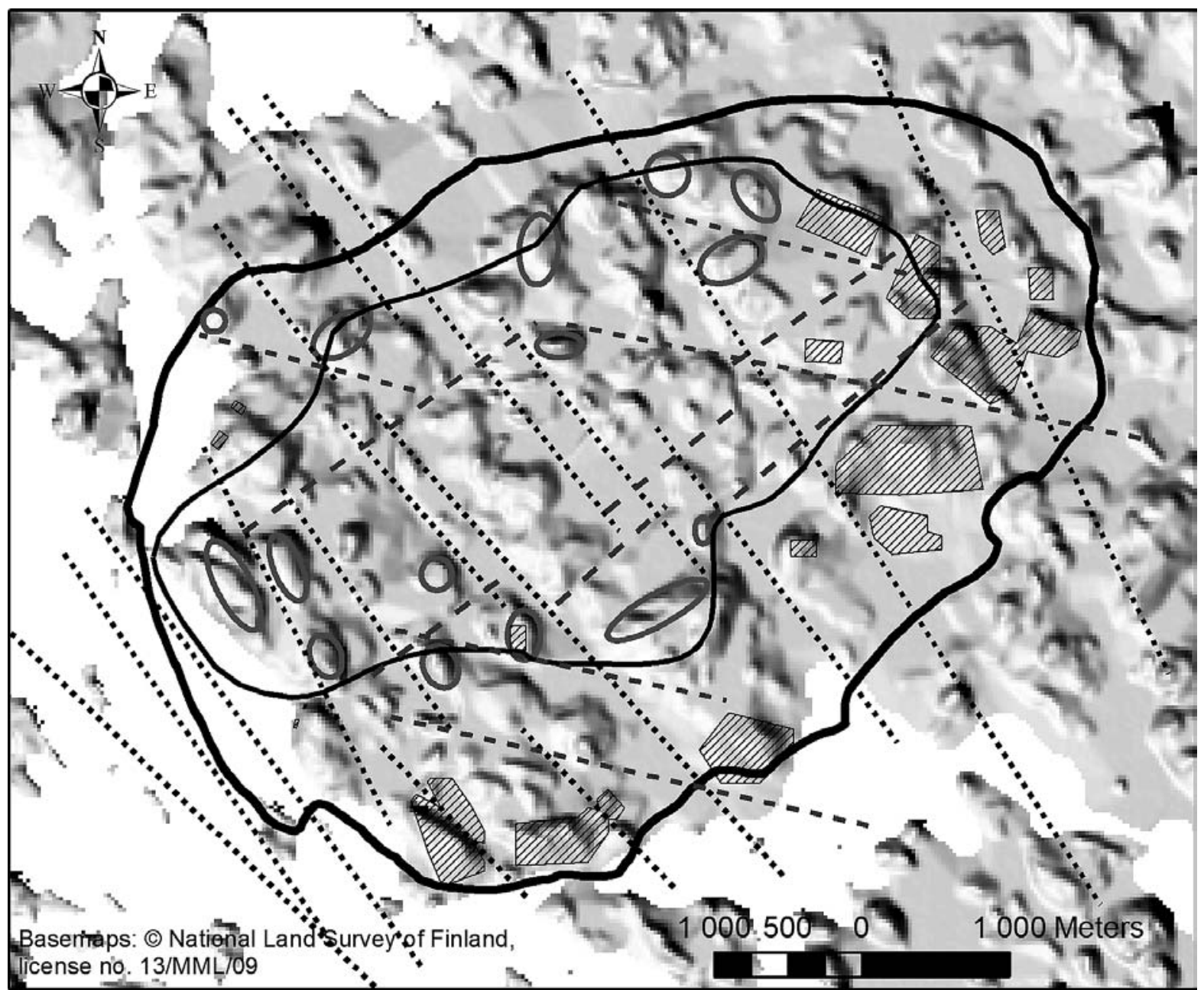

\section{Quarry $\bigcirc$ Prospect}

Fig. 7. Main fracture zones (dashed lines), natural stone prospects, and quarries within the medium-grained porphyritic granite body. Fracture zones are deduced from aerial photos, topographical maps, and geophysical maps. Locations of the prospects are based on our evaluation. Digital elevation model as background. For location, see Fig. 1.

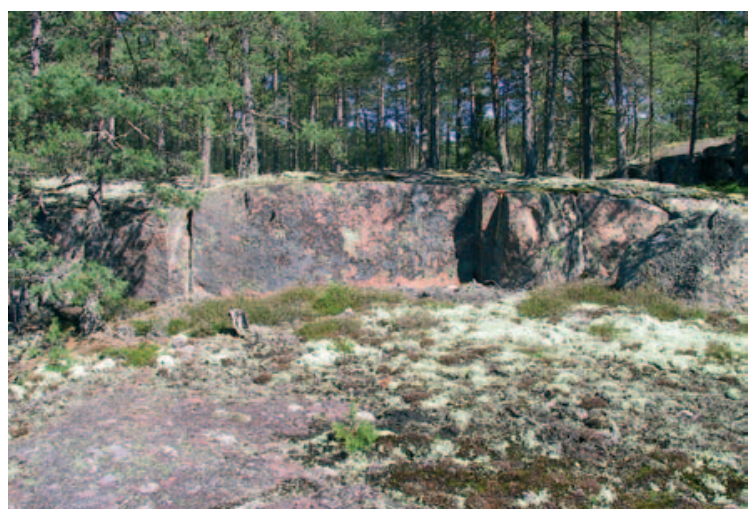

Fig. 8. Sheeting in granite at the top of a terraced outcrop. Length of the hammer handle is $63 \mathrm{~cm}$. of usable and easily accessible natural stone material.

Granites with the widest spacing of vertical fracturing are found in topographic plateaus with only a moderate elevation $(5-10 \mathrm{~m})$ in respect to the surrounding areas. These low plateaus, however, are also characterized by close spaced sheeting near the terrain surface (which can become wider spaced downwards) and an intense and penetrative horizontal or subhorizontal microfracturing in the rock (as seen, e.g. in drill cores). These low relief areas seem not to be related to regular steep fracture zones in their immediate vicinity and hence, the dense microfracturing may be due to the lack of 
existing macrofractures along which the rock pressure could have been released. The process of glacial abrasion in these rocks is probably the reason for the moderate elevation in contrast to surrounding more crushed (ice plucked) low topographies, or higher plateaus with more spaced sheeting but denser vertical fracturing (cf. Dühnforth et al., 2010). In the low plateaus the influence of fracturing on the quality of stone is crucial: the uppermost production layers are unusable as natural stone.

Estimation of fracturing is of course always critical in assessing whether a rock is sound and suitable for quarrying (see below). In this study we give it less weight because we observe few differences in patterns of fracturing or fracture zones between the different magmatic phases of our concern. In Vehmaa, the local topography mirrors the spacing and type of fracturing and can be used as a rough indicator of potential natural stone occurrences.

\section{Natural stone potential and distribution of the quarries}

The pyterlite has typically a wide spacing of fractures, and sites where the fracture spacing is wide enough for extraction can easily be identified. Spacing of the vertical fractures is typically several metres, even up to 10 metres (Fig. 9). Some of the fractures are filled with secondary minerals or have

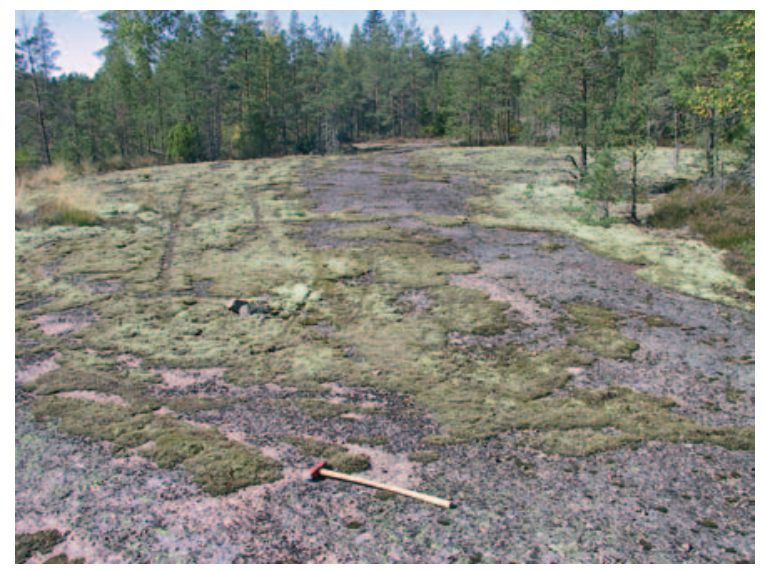

Fig. 9. Widely spaced vertical fracturing in a pyterlite outcrop. Length of the hammer handle is $63 \mathrm{~cm}$. a red colorization. Sheeting occurs at intervals of one to several metres. Composite aplite and pegmatite dykes with quartz veins are found, as well as felsic and mafic igneous enclaves and supracrustal xenoliths. The colour of the pyterlite varies from red to brown even within small areas. Greenish varieties also occur. To date, the brown variety has been the commercially most attractive and is quarried at two sites with the trade names of Esko Brown and Antique Brown. The local variations in colour (red/brown) and the different kinds of dykes pose the main challenges in the pyterlite as a commercially viable stone quality. The greenish pyterlite could have a commercial potential but outcrops are found in areas unsuitable for extraction because of their location close local settlements.

The coarse-grained porphyritic granite has a wide spaced fracturing with an orthogonal fracture pattern. Locations with potential for extraction can be found, but today, the granite has been quarried only locally for stone base foundations. Spacing of the vertical fractures is typically several metres. Horizontal fractures occur with intervals of around two metres. The colour is pale red with an occasional pastel tint because of light green plagioclases. Fluids along fractures have caused a red colorization in the vicinity of some fractures. Sparse aplite dykes cut the granite. The commercial potential of the granite depends upon the colour. The greenish granite with pastel tint could have the best present potential as a commercial natural stone.

The satellite intrusion with the even-grained granite (Balmoral Red fine-grained) is a traditional stone producing area with at present three production areas (Selonen \& Härmä, 2003). The appearance of the even-grained granite is similar to that of the outer medium-grained granite in the main batholith except for a smaller grain size and a more intensive red colour. The fracturing is generally orthogonal but in places has multiple directions. Maximum spacing of the vertical fractures is $3-4 \mathrm{~m}$ as measured along cleaned traverses in prospects. Aplitic dykes and patches, miarolitic cavities, redcoloured joints, and greisen-like veins occur. The relatively close spaced fracturing, and the veins and inclusions are the main challenges in quarrying here. 
The porphyry aplites have too closely spaced fracturing for industrial extraction, and they have been quarried only locally for stone base foundations. The colour of the rock is grey or red. The grey types have a wider spaced fracturing than the red ones, and could have potential for special purposes, provided that the colour is commercially attractive.

\subsection{Medium-grained porphyritic granites}

The outer medium-grained porphyritic granite (OG) (Balmoral Red coarse-grained) is the economically most important rock type for the present in the Vehmaa batholith (Selonen \& Härmä, 2003). As mentioned before the abandoned and present quarries are concentrated to the outer margins of the medium-grained porphyritic granite body (later identified as OG) and located in the western, southwestern, southern, eastern, and northeastern parts of the granite body (Fig. 7). Today, the active quarries are only found in the OG.
The main difference between IG and OG as a source for natural stone is the colour contrast between the matrix and the K-feldspar phenocrysts. The appearance of the outer granite (OG) is characterized by a clear contrast between the dark matrix and the red K-feldspar clusters (Fig. 2A), whereas the contrast is less distinct in the inner granite (IG) because of red feldspar in the matrix, which gives the granite a more "blurred" appearance (Fig. 2B). The colour of both granite types varies from red to light red, but generally the outer granite (OG) has a brighter colour.

The wide spaced fracturing in the IG and OG granites is open and mainly orthogonal with two vertical fracture directions perpendicular to each other accompanied with well-developed sheeting. The sheet fractures occur in average approx. two metres apart but the sheeting can become more closely spaced closer to the surface. The spacing of the vertical fractures is in average approx. three metres, as measured along traverses. The wide spaced horizontal fracturing is confirmed by GPR measurements (Fig. 10). No difference in fracturing style or

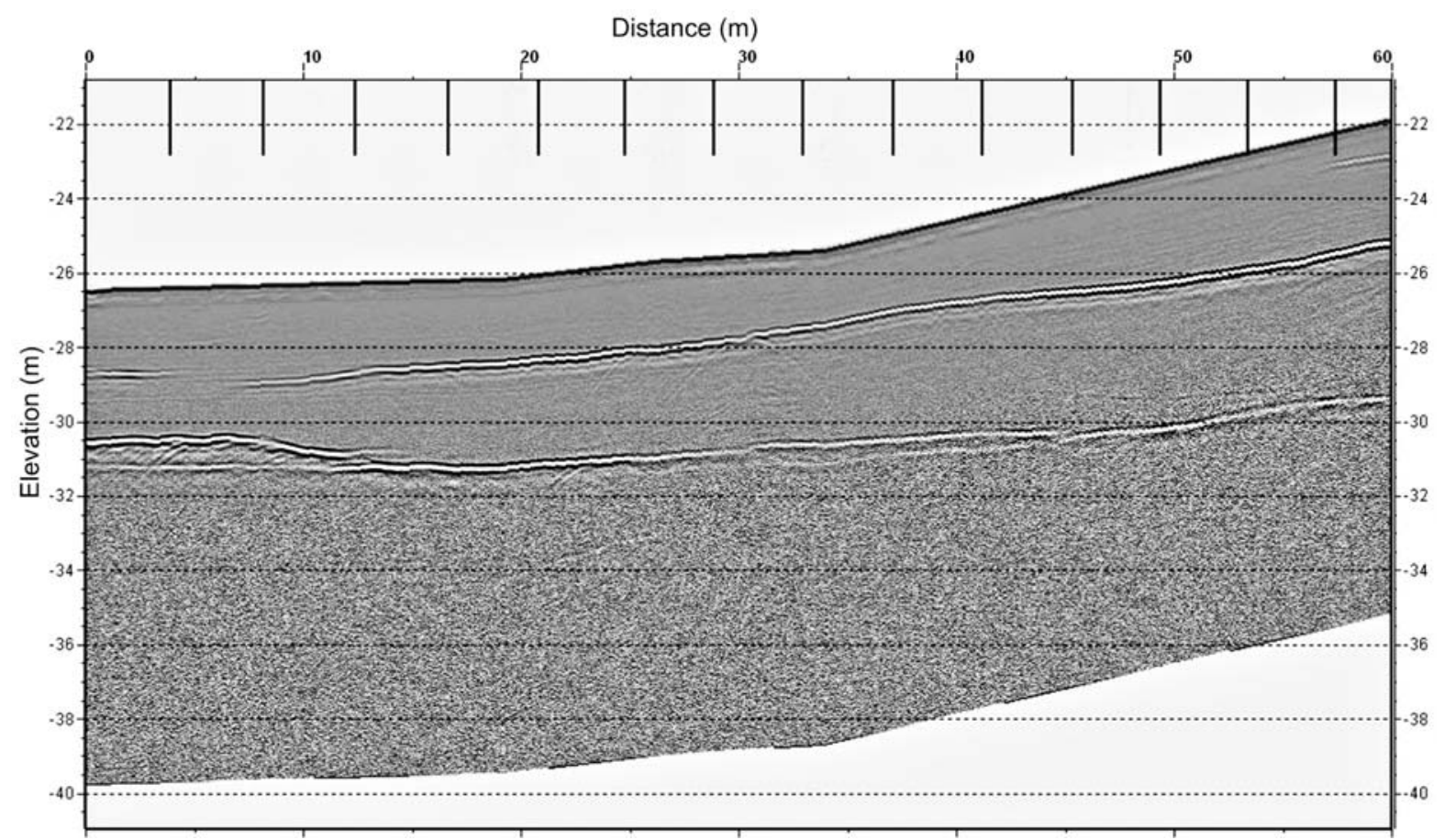

Fig. 10. Ground penetrating radar profile, showing sparse subsurface horizontal fracturing in a medium-grained porphyritic granite (OG). Used frequency $200 \mathrm{MHz}$ with 200 ns measurement time. 
fracture spacing can be observed between the two types (IG and OG) of granite. Lens-shaped or rounded aplitic inclusions and small mafic microgranular enclaves occur in both types of granite, as well as dark schlieren structures, which are considered as flaws in the appearance of the granites. Our evaluation of the two granite types (IG and OG) showed that areas with potential for natural stone can be found in both types of granite (IG and OG) regardless of the textural type (Figs. 7 $\& 11)$.

\section{Discussion}

The analysis of the geological characteristics of the Vehmaa batholith and the evaluation of the natural stone resources in the area provide a framework for considering the geological constraints for the localization of the natural stone deposits in the batholith. In the following sections we discuss some general constraints concerning the localization of deposits in granites in southern Finland with reference to Vehmaa, and continue with the more specific magmatic constraints for the Vehmaa batholith.

\subsection{Aspects of general geological constraints}

The relative age of the intrusion is a good indicator when searching for plutons with a wide spaced jointing on a regional scale. The plutons, which have intruded during a late stage in, or after of the dominant regional deformation, have a relatively wide spacing of fractures and a high intrinsic potential for natural stone. Therefore, regionally, the undeformed and anorogenic Vehmaa batholith is a location with a high potential for natural stone, as well as other rapakivi granite intrusions in Finland. Nearly $70 \%$ of all granite production in Finland comes from the rapakivi granite areas (Härmä \& Selonen, 2008).

The structural position of intrusions is an important constraint for localization of potential areas for natural stone. Plutons, which are parallel to

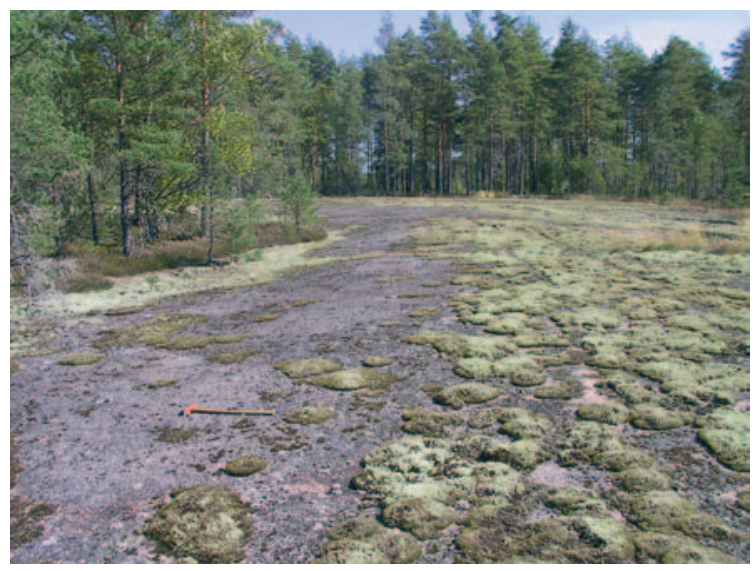

Fig. 11. Example of a natural stone prospect in a medium-grained porphyritic granite (IG). The mean spacing of vertical fractures in the area shown by the picture is $3.1 \mathrm{~m}$ as measured by tape. Length of the hammer handle is $63 \mathrm{~cm}$.

the present erosion surface expose a large area of raw material for natural stone, while subvertical intrusions have a smaller area of exposion. The Vehmaa batholith is composed of several subhorizontal sheet-like intrusions roughly parallel to the exposed peneplane with the result that large areas of rapakivi granite with good potential for natural stone are exposed. The structural position of intrusions in relation to the peneplane, is an even more important control in orogenic and ductily deformed intrusions because of folding (Selonen, 1998; Selonen et al., 2000; Nyman, 2007; Carvalho et al., 2008).

The crustal depth level of exposure through the granite intrusions also seems to have an important influence on the quality of the rocks. For instance, the southwestern part of the large Alland rapakivi batholith (to the west of the Vehmaa batholith, see inset in Fig. 1) exposes a superficial (subvolcanic) level of intrusion comprising fine to mediumgrained quartz porphyries (Ehlers, 1989). The rocks have beautiful and intensive colours but they are strongly and unevenly fractured and break up into small and uneven blocks (Selonen, 1994). The eastern part of the Aland batholith exposes a deeper section consisting of well-crystallized coarse rapakivi granites (Ehlers, 1989) with large exposures of sound rocks with wide spaced and systematic verti- 
cal fractures (Selonen, 1994). The crustal level of the intrusion of the Vehmaa batholith is ca 2 kbars according to Väisänen et al. (1994), and no superficial rocks are exposed. The granites of the central (deeper) parts of the large Viborg rapakivi batholith allow for production of large blocks while superficial volcanic varieties are exposed closer to the contacts (e.g. Härmä \& Selonen, 2008).

\subsection{Magmatic history and localization of natural stone deposits in the Vehmaa batholith}

Previously, it was unknown why almost all the exhausted and present natural stone quarries were situated along the margins of the medium-grained porphyritic granite body, but by defining the outer intrusion (OG) of the granite as a separate magmatic sheet, our studies connect the location of the quarries specifically to the intrusion history of the batholith, which gives a geological explanation for an observed fact.

No difference in fracturing style or fracture spacing can be seen between the two intrusion phases of granite, and the large scale fracture zones cut through both granites (IG and OG). The granites are quite equally well-exposed, and outcrops with large volumes of rock can be found in both types. Our evaluation showed that potential for natural stone can be found in any of the two types of granite (IG and OG), indicating that the general quality of the both medium-grained porphyritic granites is good enough for quarrying. Yet, the quarries are found in the outer intrusion (OG) of the granite.

The only main distinction in natural stone properties between the OG and the IG is the slight difference in texture and appearance. The outer intrusion (OG) has a marked contrast in colour between the clusters of red K-feldspars and the darker matrix in contrast to the more "uniform" granite in the central intrusion, making it commercially more interesting than the almost identical central part of the intrusion. This small difference in appearance is the reason why most quarries are found only in the outer intrusion (OG) of the medium-grained porphyritic granite. Prospects in the inner granite are equally good but the stone has an appearance that makes it less attractive according to the fashion of today. Furthermore, the fact that the inner granite is different in appearance from the classic Balmoral Red has influenced the market so that over time, the outer granite has remained commercially the most interesting stone quality within the mediumgrained porphyritic granite body.

In most of the rapakivi areas of southern Finland there are plenty of sound rocks suitable as natural stone (Selonen, 1994; Härmä \& Selonen, 2008), but most of these sites are not (yet) exploited because of limited interest from the market due to less interesting appearances or other features, making them unsuitable for marketing. In the Vehmaa batholith most of the magmatic phases have potential for natural stone. Portions of feasible stone are identified in all the intrusive phases, except for late phase of porphyry aplite which has too closely spaced fracturing for industrial extraction. In spite of this, the quarries are concentrated in two types of rapakivi granite only: the even-grained granite in the little intrusion at the eastern margin of the batholith and the outer intrusion of the mediumgrained porphyritic granite in the centre of the batholith. This is because only those stones with a colour and a general textural outlook (appearance) that is presently commercially attractive are quarried. Hence, good knowledge of the global stone markets and prevailing trends is needed for a correct evaluation of the appearance and the commercial potential of a stone. However, in exploration, prospects with low immediate commercial interest should not be automatically rejected, because later they can become interesting due changes in fashion and demand. From a geologist's point of view we can state that it is the intrusion history of the batholith and the associated appearance of the rock, which ultimately constrains the location of the commercially viable stone qualities in the Vehmaa batholith. 


\subsection{Geological exploration models}

The intrusion model created for the Vehmaa batholith could be applicable for the formation of the other rapakivi granite intrusions in Finland, as well. The presence of superficial volcanic types of rapakivi rocks along the margins of the batholiths (indicating a high level of erosion), and their general setting of multiple overlapping intrusion complexes, together can imply an emplacement mechanism related to the formation of syn-intrusional volcanic calderas, eroded today to expose their subvolcanic batholiths. If the amalgamated smaller intrusions are petrologically similar to the previous ones, and if the contacts, in the prevailing flat topography, are gently dipping, this mode of formation can be effectively concealed and ignored in the field. As shown by this case study (and, e.g. by Arponen et al., 2009), detailed geological investigations may be needed in order to identify all the different components, appearances, and colours in the rocks and intrusions. Even small and superficially "simple" plutons can be composed of several intrusion phases, with differing commercial potential, that can be revealed by careful investigations (Arponen et al., 2009). We believe that with a thorough study of the different magmatic components and colours, the distribution of the present natural stone deposits in the rapakivi areas can be explained more precisely than before. Furthermore, for successful prospecting of natural stone in these batholiths, the proper identification of the intrusion phases is of major importance.

By identifying and mapping the several intrusion phases of the Vehmaa batholith, and by the help of aeromagnetic maps and detailed AMS studies, we can set the present and past stone quarries into a geological framework. By constructing a proper geological evolution model (incl. topography) for the study area all the relevant factors can be identified and the localization of deposits explained. This is very important for future exploration while making prognoses on areas with potential for natural stones (Selonen et al., 2000; Heldal \& Arvanitides, 2003; Heldal et al., 2008;
Selonen, 2008). To define geological constraints and to identify geological environments beneficial for economic mineral resources is a well-established method in ore exploration and the same approach should be applied in prospecting for natural stone. This would allow us to make testable geological exploration models, increasing the efficiency of the exploration and focusing on areas with the highest commercial potential. The greatest benefit of the models is gained when applied in an early stage of an exploration process. Natural stone assessment is often described as a step-by-step process (Luodes et al., 2000; Selonen et al., 2000; Luodes, 2003; Heldal \& Arvanitides, 2003; Selonen \& Heldal, 2003; Ashmole \& Motloung, 2008; Carvalho et al., 2008) aimed at identifying new natural stone deposits. We recommend that creation of at least a provisory geological exploration model is included in the evaluation process. The use of scientific geological exploration models and the stepwise exploration process integrated with good knowledge of the markets (appearance of stone) creates the basis for successful exploration and assessment of natural stone.

\section{Conclusions}

Our conclusions are: (1) the localization of natural stone deposits in the Vehmaa batholith is primarily constrained by the magmatic history of the batholith resulting in intrusions of different appearances with different commercial potential; (2) by conventional, but detailed geological methods (field mapping, fracture analysis, geophysics etc.) the geological constraints for deposits of natural stone can be defined; (3) geological exploration models are beneficial in exploration for natural stone deposits and should be included in the exploration process; (4) the commercial appearance of a stone is the ultimate criterion to whether an otherwise feasible natural stone prospect will be an object of extraction or not, but it is outside the realm of strict technical and geological considerations. 


\section{Acknowledgements}

Critical reviews by Prof. Ilmari Haapala and Mr. Tom Heldal considerably improved the text, which is gratefully acknowledged.

\section{References}

Arponen, E., Härmä, P., Selonen, O. Luodes, H. \& Pokki J., 2009. Anorthosite and spectrolite in the Wiborg rapakivi granite batholith and the lithological control of spectrolite deposits. Geological Survey of Finland, Report of Investigation 178, 1-41. (in Finnish with an English summary)

Ashmole, I. \& Motloung, M., 2008. Dimension stone: the latest trends in exploration and production technology. In: The International Conference on Surface Mining 2008 Challenges, technology, systems and solutions - Papers. The Southern African Institute of Mining and Metallurgy, Johannesburg, Republic of South Africa, 35-70.

Bradley, F., Founti, M. \& Kontodimos, K., 2004. Commercial characteristics. In: Founti, M. (ed.), Stone for construction and architecture from extraction to the final product. OSNET Editions Volume 10, NTUA, Athens, Greece, pp. 17-26.

Carvalho, J.F., Henriques, P., Falé, P., \& Luís, G., 2008. Decision criteria for the exploration of ornamental-stone deposits: Application to the marbles of the Portuguese Estremoz Anticline. International Journal of Rock Mechanics \& Mining Science 45, 1306-1319.

Dühnforth, M., Anderson, R.S., Ward, D. \& Stock, G.M., 2010. Bedrock fracture control of glacial erosion processes and rates. Geology 38, 423-426.

Ehlers, C., 1989. Rapakivi granites and postorogenic granites in the area between the Aland and the Vehmaa batholiths. In: Symposium Precambrian granitoids. Petrogenesis, geochemistry and metallogeny, August 14-17, 1989, Helsinki, Finland. Excursion A 1: rapakivi granites and postorogenic granites of southwestern Finland. Geological Survey of Finland, Guide 27, 19-29.

EN 12670, 2001. Natural stone-Terminology. European standard. European committee for standardisation. Brussels. Belgium. 49 p.

Härmä P. \& Selonen, O., 2008. Surface weathering of rapakivi granite outcrops - implications for natural stone exploration and quality evaluation. Estonian Journal of Earth Sciences 57, 135-148.

Heldal, T. \& Arvanitides, N., 2003. Exploration and prospecting - economic target selection. In: Terezopoulos, N. \& Paspaliaris, I. (eds.), Dimension stone quarrying in Europe and stability of quarrying operations. OSNET Editions Volume 2, NTUA, Athens, Greece, pp. 13-23.

Heldal, T., Kjølle, I., Meyer, G.B. \& Dahlgren, S., 2008.
National treasure of global significance. Dimension-stone deposits in larvikite, Oslo igneous province, Norway. Geological Survey of Norway Special Publication 11, 518.

Kanerva, I., 1928. Über das Rapakivigebiet von Vehmaa im südwestlichen Finnland. Fennia 50, 40, 1-25.

Karell, F., Ehlers, C., Airo, M.-L. \& Selonen, O., 2009. Intrusion mechanisms and magnetic fabrics of the Vehmaa rapakivi granite batholith in SW Finland. Geotectonic Research 96, 53-68.

Lindberg, B. \& Bergman, L., 1993. Pre-Quaternary rocks of the Vehmaa map-sheet area. Geological map of Finland 1:100 000. Explanation to the maps of Pre-Quaternary rocks. Sheet 1042 Vehmaa. Geological Survey of Finland, Espoo, Finland. 56 p. (in Finnish with an English summary)

Lombardero, M. \& García-Guinea, J., 2001. Geological factors in the roofing slate quality. In: Sandrone, R. (ed.), International workshop "Dimension stones of the European Mountains". Luserna San Giovanni - Torre Pellice (TO) 10-12 giugno 2001. Proceedings, Politecnico di Torino, Italy, pp. 69-74.

Lorenz, W. \& Gwosdz, W., 2003. Manual on the geologicaltechnical assessment of mineral construction materials. Geologische Jahrbuch, Reihe H, Heft SH 15. Hannover. $498 \mathrm{p}$.

Luodes, H. 2003. Exploration of natural stones in Finland. In: Kuula-Väisänen, P. \& Uusinoka, R. (eds.), Workshop on building stones. Helsinki, Finland August 7, 2001. Tampere University of Technology. Laboratory of engineering geology. Report 56, 11-13.

Luodes, H., Selonen, O. \& Pääkkönen, K., 2000. Evaluation of dimension stone in gneissic rocks - a case history from southern Finland. Engineering Geology 58, 209-223.

Meriluoto, A., 2008. Puulan graniitin ja Viipurin rapakivibatoliitin Laapaksen alueen rakennegeologinen tulkinta. [Structural analysis of the Puula granite and the Laapas area in the Wiborg rapakivi granite batholith]. MSc thesis, University of Turku, Department of Geology. (in Finnish).

Nyman, R., 2007. Geological, geophysical, and structural features of the Kuru batholith. MSc thesis, Åbo Akademi University, Department of geology and mineralogy, Turku.

Primavori, P., 1999. Planet Stone. Giorgio Zusi Editore, Verona. $326 \mathrm{p}$.

Rämö, O.T. \& Haapala, I., 2005. Rapakivi granites. In: Lehtinen, M., Nurmi, P.A. \& Rämö, O.T. (eds.), Precambrian Geology of Finland - Key to the Evolution of the Fennoscandian Shield. Elsevier, Amsterdam, pp. 533-562.

Selonen, O., 1994. K.H. Renlundin säätiön rakennuskivitutkimukset 1982-1993. [Natural stone investigations by the K.H. Renlund Foundation 1982-1993]. K.H. Renlund Foundation, Turku, Finland. 43 p. (in Finnish) 
Selonen, O., 1998. Exploration for Dimension Stone Geological Aspects. Academic dissertation. Åbo Akademi University, Department of Geology and Mineralogy. Turku.

Selonen, O., 2008. Geological constraints on localization of natural stone deposits. In: Wahl, N.A. (ed.), $28^{\text {th }}$ Nordic Geological Winter Meeting, January 7-10, 2008 Aalborg, Denmark. Abstract volume, Aalborg University, pp. 48.

Selonen, O. \& Härmä, P., 2003. Stone resources and distribution: Finland. In: Selonen, O. \& Suominen, V. (eds.), Nordic Stone. Geological Science series, UNESCO publishing, Paris, France, pp. 19-29.

Selonen, O. \& Heldal, T., 2003. Technologies. In: Selonen, O. \& Suominen, V. (eds.) Nordic Stone. Geological Science series, UNESCO publishing, Paris, France, pp. 42-50.

Selonen, O., Luodes, H. \& Ehlers, C., 2000. Exploration for dimensional stone - implications and examples from the
Precambrian of southern Finland. Engineering Geology 56, 275-291.

Selonen, O., Ehlers, C., Luodes, H. \& Lerssi, J., 2005. The Vehmaa rapakivi granite batholith - an assemblage of successive intrusions indicating a piston-type collapsing centre. Bulletin of the Geological Society of Finland 77, 65-70.

Shadmon, A., 1996. Stone: an introduction. Second edition. Intermediate Technology Publications, London. 172 p.

Väisänen, M., Hölttä, P., Rastas, J., Korja, A. \& Heikkinen, P., 1994. Deformation, metamorphism, and the deep structure of the crust in the Turku area, southwestern Finland. In: Pajunen, M. (ed.), High temperature-low pressure metamorphism and deep crustal structures. Meeting of IGCP project 304 "Deep crustal processes in Finland", Sept. 16-20, 1994. Geological Survey of Finland, Guide $37,35-41$. 